\title{
SOME RESULTS OF THE PENNSYLVANIA PUBLIC SERVICE COMPANY LAW:*
}

During the past year, the Commission appointed under the Public Service Company Law of July 26 , 191 $3,{ }^{1}$ has organized and proceeded to the performance of its duties. That the confidence which the public had in the character and reputation of the members of this Commission was not misplaced has been proven by the patience and courtesy they have shown at the hearings of the matters which have come before them, and by their endeavors to judge righteously and to do justice between the public and the corporations under their control.

The clear intent and purpose of the Public Service Company Law is to put the control of the corporations therein referred to in the hands of a commission with respect to service, rates and facilities to the end that there may be but one body controlling them rather than they shall be governed by various bodies, such as municipalities, courts, ctc. If for no other reason, the goverance of these corporations by a commission is of general benefit when we realize that such a commission, both in itself and in its officials, engineers, accountants, and other representatives, is skilled in the subject, and as the Commission gains still further experience in the future, will result on the one hand in fair service to the public by these corporations, and on the other in an absence of unjust competition, and the corporations will be able to receive fair compensation for fair service, with a proper return upon their investments.

This equilibrium seems to all those who have given the subject study and research to be assured through the powers given the Commission by law, and through the duties thereby imposed upon them. For example, a municipality hereafter is justly restrained from paralleling lines of a public service corporation where there is no public necessity for competition, the result of which might otherwise be to cause the loss of an honest investment by the unfair competition of a municipality through its ability to cover up, under the guise of taxation, the losses it would

*The basis of this article was an address delivered at the annual meeting of the Pennsylvania Water Works Association, October 22, 1914

${ }^{2}$ P. L. 1374.

(364) 
sustain in the operation of a plant carried on for the purpose of defeating its weaker rival. But while a public service corporation is thus freed from ruinous municipal rivalry, it is compelled to obey the regulations of the Commission with respect to its dealings with the public, whereby the users of the commodity furnished, or patrons of the service rendered by the corporation are safeguarded to the extent that such commodities and service will be supplied more satisfactorily and at no greater cost in the end than if by a municipality, whose service is without control, and whose wrong doing it would be most difficult to restrain. Again, if the control of public service corporations were vested in the governing body of a municipality, the result would be injurious to the public in several ways, particularly since the control is not in the hands of those who are expert in the subject, but rather of those whose training and daily employment are quite removed from such knowledge. So also would such control be almost universally partial and against the corporation, and the rates established by such a governing body would probably be most unjust and improper, particularly with respect to the rates to the municipality itself, it being a well settled rule of all governiments, and of all forms of justice, that those who are to judge another's cause should in no manner be interested in the result.

The purpose of this article is to discuss the decisions which have thus far been rendered by the Public Service Cominission. There have not been very many cases thus far decided, but those rulings which have been made are clear, distinct, and easily understood, and have received general public approval. In addition to the cases which have come before the Commission and have received its adjudication, there are included a few others passed upon by the courts which concern the operation of the Public Service. Company Law and construe some of its provisions.

It is believed that the chief purposes for which the Commission was organized are the prevention of unjust and unnecessary competition between public service corporations and the control of the service rates and facilities of such corporations so that the public should be served without discrimination and for a reasonable compensation. The cases may be grouped conveniently under these headings. 


\section{Prelention of Unjust and UnNecessary Competition.}

Under the Act, the consent of the Commission is required before a new public service company can be incorporated, ${ }^{2}$ or such company can exercise any right or franchise under any ordinance or municipal contract, ${ }^{3}$ or before any municipality may acquire, construct or operate a plant to furnish service to the public of the kind already being served by a company within the municipality; provided that the municipality has not, prior to January $\mathbf{r}$, 1914, begun to construct such a plant in that territory." Such consent will be given only when the Commission determines that the. granting of the application therefor is necessary for the service, accommodation, safety or convenience of the public.s The new company must show that the competition will be a public benefit. For this reason, the Commission refused its consent in in re Schuylkill Light, Heat \& Power Company's Petition. ${ }^{\circ}$ This Company presented its petition to the Commission August 19, 1913, asking its approval of an ordinance of the Borough of Ashland granting the company the right to enter upon the streets of the borough with poles and wires for the purpose of distributing light, heat and power. The Eastern Pennsylvania Light, Heat \& Power Company filed its protest to this petition to the effect that it and its successors had occupied the streets for twenty-nine years, serving the community adequately and having sufficient plant for that purpose, and without serious complaint with respect to its rates. These facts having been found, the question arose as to whether the approval of this contract with the borough would result in a public benefit. The Commission held that it would not be such a benefit and dismissed the petition, and, speaking by Mr. Commissioner Pennypacker, said :?

"The passage of the Act of July 26, 1913, and of similar acts in nearly all of the other States indicates a general judgment that a reliance upon competition between public service

\footnotetext{
Art. III, \$2 (a), P. L. 1368.

Art. III, \$2 (b), P. L 1368.

-Art. III, \$3 (d), P. L. 1368

-Art. V, \$18, P. L. 1414.

1 P. C. R. 122 (April 9, 1914).

At p. 125.
} 
companies for securing adcquate service and proper rates has not been successful, and that hereafter supervision by properly constituted authorities is to be substituted. Long experience has shown that while the temporary effect of competition between public utilities occupying the same territory is to secure lower rates, the final result is likely to be the absorption of one by the other and then an increase of rates to pay the expenses of the warfare."

And thus concluded the opinion:

"The Eastern Pennsylvania Light, Heat \& Power Company has occupied the same territory for twenty-nine years. Its plant is adequate. It has supplied the municipality and the people during the entire period with comparatively little complaint. Should its rates be unreasonable, discriminatory or unduly burdensome it is always within the power of the Commission upon proper complaint to control them and afford relief."

The case of in re Harmony Electric Company is quite similar to the preceding case. The petitioner sought the approval of a contract to furnish light and power in the Borough of Ellwood City, and was opposed by the Pennsylvania Power Company, which had been supplying that borough for many years, had over three hundred thousand dollars invested therein, and had rendered satisfactory and efficient service. The borough had a population of about four thousand five hundred, and there was no present indication of any special development in its industrial life. The very able opinion by Mr. Commissioner Brecht reviews similar decisions of other commissions. It was held ${ }^{9}$ that :

"The contract between the petitioner and the said borough should not be approved. Defore a Certificate of Public Convenience is issued it must be established that the desired service is necessary and proper for the accommodation, safety or convenience of the public. The Commission is not justified in permitting competition, nor in taking such action as to invite it, unless the area and population served, the needs of the community, or the prospects of the municipality, as based upon its growth and development, reasonably show that the public welfare demands it. The power to regulate a public utility by law is

2 P. C. R. 42 (July 3, 1914).

'At p. 42 
corollary to the duty to protect its property and the interests of the public and investors from unnecessary and ruinous competition. In doubtful cases it is safer to draw the line against, rather than in favor of, competition."

The case of Borongh of Exeter's Petition ${ }^{10}$ also is in line with the Schuylkill Case. The borough asked approval of a franchise-ordinance with the Consumers Electric Company, giving that company the right to erect poles, wires, etc., and to supply electricity to its citizens. The Citizens' Electric Illuminating Company, which had been operating for many years under the franchises granted to it, contending that public necessity did not . recjuire the operation of two companies within the borough. There was some evidence of unsatisfactory service by the latter company, and some complaint as to excessive rates. It was held :11

"Under the circumstances the contract should not be approved. Where two public service companies enter into active competition in a small field, there will be inevitable duplication of facilities, followed by merger; and as rates must, under the law, provide a fair return upon the value of the property employed in public use, they will be higher after such competition than before. The Commission cannot approve such competitions, knowing that when it is called upon to fix rates it will be compelled to provide for a return upon an investment unnecessarily made. The remedy for inadequate or unsatisfactory service, under the Public Service Company Law, is by complaint to the Commission, and not by encouraging competition."

If, however, it appears that the new company will be a benefit to the community, the consent of the Commission will be given. This was exemplified in a later petition, ${ }^{12}$ where the same borough asked approval of a contract for street lighting made with the Consumers' Electric Company. This contract was made after due advertisement for and consideration of bids, but the older company, which protested and which had been furnishing the borough for many years, declined to present a bid under the advertisement, and contended that the approval of this contract would result in a duplication of poles and wires in the streets, to

${ }^{10} 2$ P. C. R. 52 (July 21, 1914).

"At p. 52.

${ }^{13}$ Borough of Exeter's Petition, 2 P. C. R. 60 (July 21, 1914). 
the inconvenience and danger of the public. Chiefly because this oider company did not bid for the light, it was held that the borough appeared to have done the wisest thing in accepting the proposition of the new company. Such lighting being necessary for the borough, the Commission was of the opinion that the contract should be approved.

When a municipality or public service company enters into competition with an existing company, without having obtained the consent of the Commission, it will be restrained by an injunction until it obtains such permission. This was decided in Bethlehem City Water Company v. Bethlehem Borough, ${ }^{13}$ where the plaintiff, a public service company, furnished water to a portion of the defendant.borough which before its consolidation with the borough had been a part of Lehigh County. The defendant borough owned its water plant and proposed to parallel the pipes of the plaintiff. The plaintiff sought an injunction in Northampton County to restrain the laying of pipes by the borough without the approval of the Public Service Commission. It was held that a municipality desiring to extend its facilities into territory which is supplied by a public service company furnishing service of a like cliaracter will be restrained by injunction until it secures the approval of the Public Service Commission.

The approval of the Public Service Commission is not required when a company is incorporated prior to the approval of the Act of I9I3, even though it does not enter into the exercise of its rights until after the time when this Act went into effect. In Penusyliania Utilities Company v. Lehigh Nacigation Elcctric Company ${ }^{14}$ the complainant company had been engaged for many years in supplying light, heat and power by electricity to certain townships in the counties of Pike, Monroe and Northampton. The respondent company was incorporated prior to the approval of the Public Service Company Law, but had not begun the exercise of its rights and powers until after the Act went into effect, and, in so doing invaded the territory occupied and served by the complainant company. The complaint was dismissed and it was held:

201 P. C. R. 227 (May 18, 1914).

"2 P. C. R. 74 (July 9, 19r4). 
"The Commission has no authority to require a company" chartered prior to the approval of the Public Service Company Law to secure its approval before beyinning the exercise of rights and powers under its charter."

But municipalities entering into competition in public service are subject to the Act unless they have started to construct the public service plant before the Act went into effect. ${ }^{15}$ Actual construction of the plant must have been begun before that time. Mere preparatory steps are not enough. This is well brought out in in re Consolidated Water Company's Petition. ${ }^{16}$ For some time there had been an attempt of certain people in the Borough of Coudersport to secure a municipal plant without any apparent necessity therefor, there being no apparent objection to the rates of service of the existing company. Prior to January I, 1914, the borough had employed experts to investigate and report on a possible water supply, had approved a bond issue of fifty thousand dollars for the construction of a plant, had secured an option to sink test wells, had dug one well, staked out a pump house and laid a short pipe from the test well, but no bonds had been issued, definite plans completed or contracts let for the work. It also developed that prior to the construction of the plant no permit had been secured from the Commissioner of Health, as required by law. ${ }^{17}$ The water company petitioned the Commission that it request the Attorney General to prevent the borough from violating the provisions of the Public Service Company Law by introducing its water plant without the consent of the Commission, on the ground that the plant had not been commenced to be constructed before January r, I914. The Commission sustained the petition and held that the borough must obtain the consent of the Commission before proceeding to construct its plant, holding that the steps taken by the borough prior to January I, 1914, were merely such as were preliminary to the actual construction of the plant, and that without having secured a permit from the Commissioner of Health the borough did not have its water plant in process of construction by authority of law.

\footnotetext{
${ }^{25}$ Art. III, §3 (d), P. L. 1368.

st P. C. R. 190 (April 24, 1914).

${ }^{12}$ Act of April 22, 1905, P. L. 260.
} 


\section{Discrimination.}

The Act provides that a company may not receive a greater or less sum from any consumer for a like and contemporaneous service under substantially similar conditions $\mathbf{~}^{\mathbf{1 8}}$ nor may the company give any unreasonable preference to any consumer or locality, nor subject any particular person or locality to any undue or unreasonable prejudice or disadvantage. ${ }^{10}$

Thus for those sinilarly situated, the services and rates must be the same. Under these sections it has been held that a natural gas company may not allow a discount to certain patrons after the expiration of the discount period allowed in the rules on file with the Commission, and refuse it to other patrons. ${ }^{102}$ The great question always is: When is a difference in rates or service justified? The leading case is Goerlich v. Bethlehem City Water Company. ${ }^{20}$ The complainant alleged that the water company charged different rates for the same service in the same borough by allowing a discount of twenty-five per cent. for prompt payment of bills by patrons in certain streets; and to those in other streets a discount of forty per cent. It appeared that the property of the defendant company was worth one million two hundred and fifty thousand dollars and that its net earnings were about thirty thousand dollars; its revenue was used to pay interest on its bonded indebtedness and for cost of extending its plant, and no dividends had been declared to its stockholders. Following the authority of Hoo'er v. Pennsylvania Railroad Company, ${ }^{23}$ and Railroad Company v. Behlmer, ${ }^{22}$ it was held that the discrimination forbidden by the Act is that of a charge "for a like and contemporaneous service under substantially similar circumstances and conditions". Competition real and substantial, and which exercises a potential influence on rates, may create such a dissimilarity of circumstances and conditions that a lower rate at

"Art. III, \$8 (2), P. L. 1393.

"Art. III, \$8 (b), P. L. 1393.

"In re Allowance of Discount after Expiration of Discount Period. 2

P. C. R. 127 (September 1, 1914).

* I P. C. R. 213 (June 2, 1914).

" $156 \mathrm{~Pa} .220$ (1893).

${ }_{175}$ U. S. $671(1900)$. 
the competitive point will not come within the prohibition of the Act. Whether competition does produce such dissimilarity must be determined from the facts of each case as it arises. The ruling by Mr. Commissioner Pennypacker, is of much importance: ${ }^{23}$

"In the present case with respect to the streets to whose residents the greater discount was allowed by the respondent, there was a competition of a serious character. To these residents another supply was offered at lower rates. The undisputed testimony is that it was necessary "to meet these rates or lose the business entirely'. To lose the business would be to render valueless the investment in that part of the plant. The competition was the more threatening because of the fact that it had the strength and power of the municipality supporting it. As to what constitutes such competition as will create a dissimilarity of circumstances and conditions must be determined from the facts of each case as it arises. After giving careful consideration to the ascertained facts and the situation as it exists in West Bethlehem, it is our conclusion that such dissimilarlity between the conditions upon the streets named and the other exists as to make the prohibition of the statute inapplicable."

Competition, then, is enough to differentiate conditions, and it has been held in Borough of Lezuiston v. Pcnts Central Light $\mathcal{E}$ Pozecr Company,, 24 that though the rates of the company in Lewiston were four times greater than those in Huntingdon, where there was active competition, there was no discrimination.

One of the most recent decisions of the Commission, known as the "Anthracite Coal Rates Case"," intimates that distance may justify differences. It was claimed by the petitioners that the freight rates on coal from the anthracite regions to Philadelphia were unreasonably high, and were discriminatory. The very elaborate opinion of the Commission sets forth an historical review of the modes of transportation of anthracite coal, the changes which have been brought about in this transportation, the routes, distance and cost of transportation, and a comparison of the cost of and rates for carrying bituminous coal from the region where it is mined, and, pointing out that the rate for

\footnotetext{
"At p. 216.

${ }^{24} 2$ P. C. R. 249 (November 6, 1914).

${ }_{2} 2$ P. C. R. 313 (December 12, 1914).
} 
anthracite coal carried to Philadelphia and intended for transshipment to New York, Boston and other ports "outside the capes" was forty cents per ton less than that intended for local delivery in Philadelphia, holds that the rate for such delivery should be reduced to equal the difference. It is of value to quote an important portion of this opinion:26

"On the other hand, the relation of Philadelphia to the anthracite coal deposits presents to us an extremely unusual situation. A city, whose founders located it upon the banks of a river, may well claim that it is entitled to the benefit of the transportion which the facilities of the river afford. An iron furnace which is near the ore beds, or the lime beds, or the fuel supply derives an advantage in its trade output because of the fact, and surely the proximity of Philadelphia to the deposits of anthracite coal is a natural advantage of whose benefits she ought not to be deprived. The very purpose which the Commonwealth had in view in granting the rights and privileges contained in the charter of the Philadelphia and Reading Railway Company was that the anthracite coal might be carried to Philadelphia, and the compensations to the State were that her citizens should be so supplied. We may all rejoice that the usefulness of the railroad has been extended to other States, and to other activities, but its primary object should not be permitted to be forgotten. Any effort to make Philadelphia pay higher rates because her only means of securing this necessity of life is through the transportation afforded by the respondent roads, and in order that consumers in Boston or New Orleans may get their coal more cheaply, would be a reversal of the natural order of events, and ought not to be permitted."

The significance of this language is that it foreshadows future rulings to the effect that rates for such important commodities as coal must bear relation to the proximity of the point of delivery to the mine from which the coal is shipped, a ruling which, carried to its logical conclusion, must mean that those - who are nearer to a raw material should not be required to pay therefor a cost equal to those more remote. The importance of this ruling is most apparent, and, if sustained, will be far reaching, for the time may come when the commissions, National or State, will hold, or legislation will require, that rates of freight shall be upon a per ton-mile basis.

*At pp. 327, 328. 
The purpose for which the service is used is not enough to make the circumstances dissimilar, and justify a difference. Thus in Birdsboro Stone Company v. Philadelphia \& Reading Railw'ay Company', ${ }^{27}$ the rate charged the complainant for crushed stone for commercial purposes was more than was charged for similar freight on stone used for railroad ballast. It was held that this was discriminatory and gave an unreasonable preference.

The solution of the question of discriminatory rates in a community were, for example, a water company, in order to reach customers on elevations, must go to unusual expense, and therefore be justified, it would be urged, in charging a higher rate for this service than to others to whom the water can be served without this extra expense, is awaited with interest. This is the converse of the proposition contained in the Goerlich case, ${ }^{28}$ where the objection was to lowering rates to meet competition, but, by the same reasoning as is given in that case, it could be held that the conditions are not the same, nor is it an unreasonable discrimination to make a higher charge to those for whom the service costs more to the public service company than to others.

\section{Reasonableness of Rates.}

The Act provides that a company must furnish its service at reasonable rates and in conformity with the reasonable orders of the Commission $;^{29}$ and the Commission is given power to inquire into and regulate the rates of the company. ${ }^{29 .}$ The test of reasonableness is whether the company is earning a return equal to legal interest on the investment. If the company is not earning as great a return as that, the public cannot complain that the rates are unreasonable.

In Matheson v. Middletozen \& Swatara Consolidated Water Company, ${ }^{30}$ complaint was made against alleged unjust and unreasonable water rates in the borough of Middletown. It was found that the value of the plant was approximately one hundred

\footnotetext{
${ }^{2}$ P. C. R. 264 (December 4 r 1914).

* Supra, n. 20

* Art. II, §I (b), P. L, 1377; Art. III, §I (a), P. I. 1386.

" 2 Art. V, \$1, P. L. 1402.

* P. C. R. 187 (May 7, 1914).
} 
and forty thousand dollars, and the net revenue about eight thousand dollars, without making provision for a sinking fund or depreciation. As the company was not earning a net revenue equal to legal interest on the value of the plant, nor "an income more than is fairly due after deducting the proper charges and necessary expenses incident to the conduct of its business" the complaint was dismissed. The same conclusion was reached in Ernst v. Glenside Water Company.91 Glenside is a small village lying directly across the Schuylkill River from Reading, and is connected with the latter city by a bridge. It contains about eighty houses, but has no public buildings, manufactories, or warehouses witlin its borders. The village is therefore, wholly a residential community. The people of Glenside have been furnished with water for domestic and other incidental consumption by the Glenside Water Company, a corporation which was chartered in November, 1902. In May, 1903, the water company entered into a contract with the city of Reading to supply the water which the company expected to deliver to the consumers of Glenside when it commenced operations. In February, 1904, the Glenside Water Company began to supply the citizens of Glenside and continued the service until August I, IgI I, when the city was enjoined from selling water thereafter to consumers outside its limits. The complainants alleged that the rates and service of the respondent company have been unsatisfactory in that the supply of water has been inadequate, that the water furnished was unclean, and that the rates charged were excessive. The testimony showed that although the rates charged were higher than those in a large city nearby, the company had been operating it at a loss, had not paid its officers and operators any salaries, and had but few customers, as it was located in a small community. The Commission held that the rates charged were reasonable. The fact that the rates were lower in a large community nearby did not prove that the higher rates charged in this small community were unreasonable.

The Act further provides that the Commission, when after a hearing it is decicled that the rates are "unjust, unreasonable or

nz P. C. R. Irg (August 18, 19r4). 
inadequate", may determine what are the maximum reasonable rates thereafter to be charged. ${ }^{32}$ An instance of the exercise of this power is shown in the recent decision of Business Meta's Association v. Pcnnsylzania Railroad Company.33 Here the railroads entering Philadelphia after having shown that they were not earning a reasonable return on their local passenger service, were allowed to make certain advances in their rates.

The Commission has control over the rates charged by a public service company for service to a municipality, even though this charge is fixed by a contract between the company and the municipality. In Turtle Creck Borough v. Pennsylvania Water Company,, ${ }^{34}$ a borough granted a franchise to a water company and provided that "the rates charged by said company for water furnished for domestic purposes by contract or by meter measurement, shall not exceed the rates now charged by the city of Pittsburgh", but contained no definite schedule of rates and was not limited in time. In Bellevue Borough v. Ohio Valley Water Company;, ${ }^{35}$ the borough gave the water company the right to lay its pipes and mains in the streets, with the stipulation that certain specified rates should be charged the borough and its inhabitants for water. It is to be noted that in the Turtle Creek case the rates were indefinite, while in the Bellevue case they were definite, but both were for an unlimited time. The court in its opinion in the Bellevue case says:

"Is such a contract binding in the face of the declared statutory policy of the law that the Public Service Commission shall have the power to inquire into and determine the reasonableness of rates in all such cases? This question was answered adversely to the contention of appellants in Turtle Creek Borough v. Pentsyli'ania Water Company. We did not then decide whether a contract between a borough and a water company, for a definite term of years and for specified rates during the limited term, would be enforced as between the parties, because that question was not then raised; and it is not raised now, so that this will be left as an open question until it is pre-

\footnotetext{
Art. V, \$3, P. L 1403.

22 P. C. R. 262 (December 12, 1914).

"243 Pa. 415 (January 5, 1914).

* $245 \mathrm{~Pa}$. II4 (April 20, 1914).
} 
sented in concrete form upon facts calling for a decision of the point. We did decide in that case that a contract of this kind, unlimited by its terms, and hence indeterminate as to time could not be enforced indefinitely, and must give way to the general policy of the law under which the legislature created a special tribunal to pass upon and determine questions relating to the reasonableness of rates charged by public service corporations."

We may therefore conclude that the Public Service Commission has control of the rates of a public service company, even if those rates have been agreed upon between a borough and a company for an indefinite period of time, leaving open only the question as to whether the courts will hold that the Commission has the same power with respect to an agreement for rates for a definite period of time. While the Supreme Court takes care to leave this question undetermined, it is not difficult to read between the lines that when the question is squarely raised it will likewise hold that rates by contract are subject to the control of the Public Service Commission to determine whether or not they are reasonable or unreasonable under changed conditions. This opens a wide door for inquiry and it is perhaps not necessary to discuss it at length, but it furnishes much food for thought.

The Commission, however, may not assume control over municipalities with respect to powers given them by law. On June 27, 1913, while the Public Service Company Law was under consideration, an Act was passed entitled "An Act providing for the incorporation, regulation and government of cities of the third class", but generally known as the "Clark Bill".36 Under Clause Thirty-one of Section Three of Article Five of this Act, cities of the third class are given the power to regulate the weighing and measuring of commodities sold therein, including the measuring of gas, water and electric current, and under Clause Forty-six of the same section, cities are given power to make ordinances necessary for the proper government of the city, and to enforce the same by penalties. On February 27, 1914, with the subsequent amendment of May 29, 1914, the Council of the City of York enacted an ordinance requiring the York Water Company to

\footnotetext{
* Act of June 27,1913, P. L 568
} 
install, at its expense, and maintain meters for the measuring of water to all consumers, except those who use one faucet only, for which the minimum rate of five dollars for each day's refusal to comply with the ordinances. In York Water Company v. City of $Y$ ork, ${ }^{37}$ the petitioner alleged that these clauses of the Act of June 27, 1913, were unconstitutional because of its defective title; that the Act was repealed by the Public Service Company Law, and that the attempt to enforce these ordinances by the city of York would be an usurpation of the powers of the Commission, and hence a violation of the Act under which it was organized. In dismissing the petition on the ground that the power to restrain the enforcement of the ordinances by a municipality is not given to the Commission by the Public Service Company Law, but rests alone in the courts, the opinion by Mr. Commissioner Pennypacker says :

"Many of the propositions urged in the able argument of counsel for the petitioner may be admitted, to wit: That it was the intention of the Legislature to place in the Public Service Commission the control of the service and facilities of water companies; that it would be difficult for the water company to obey two different authorities; that the Commission has the power to require the installation of meters; that obedience to the ordinance would result in discrimination; that the Act of July 26th, 1913, repealed the Act of June 27th, 1913; and that the Act of June 27th, 1913, is unconstitutional. Assuming all of these statements of law to be correct, the inquiry still arises as to where the duty is imposed upon it, to ask the Attorney General to restrain municipalities from the passage and enforcement of ordinances, even though they be contrary to law. The Act of July 26th, 1913, gives to the Commission the power to supervise contracts between municipal corporations and public service companies, and prevents those corporations from constructing plants for public service without the approval of the Commission, but nowhere is there given power to the Commission to supervise or control municipal legislation or its consequences. There is no such violation of the Public Service Act as the Attorney General could be asked to restrain. The municipal authorities are the representatives of the people in their local affairs. This Commission ought not to assume any control over the officers of the municipalities in the performance of duties imposed upon them by municipal authority, unless it

" 2 P. C. R. I85 (October 9, 1914). 
appears with sufficient clearness that this is the meaning and intention of the legislation conferring its powers. If the Commission were to undertake to restrain municipalities in every instance where there is the possibility of infringement upon the authority of the Commission, its jurisdiction would be indefinitely extended. If, as is contended, the ordinances of the borough are in conflict with the law, it is the not unusual case of a wrong committed for the redress of which the courts are always open. In its inception the effort may be restrained, and if consummated, damages may be awarded. For these reasons the petition must be dismissed."

In conclusion, the Public Service Commission thus far has been successful in carrying out the purposes for which it was formed. That it has been a direct benefit to the public at large as well as to the public service corporations of this State seems clear, and any diminution of the powers of the Commission which would destroy its usefulness would be a wrong and an injustice to every one.

Williansport, $P a$.

C. La Rue Murson. 